Litors r r $\begin{array}{r}2016 \text { Volume 22(2): 235-253 } \\ \text { doi:10.3846/20294913.2014.994191 }\end{array}$

\title{
MULTICRITERIA ANALYSIS OF TECHNOLOGICAL INNOVATION INVESTMENTS USING FUZZY SETS
}

\author{
Asli SUDER ${ }^{\mathrm{a}}$, Cengiz KAHRAMAN ${ }^{\mathrm{b}}$ \\ ${ }^{a}$ Department of Management Engineering, Istanbul Technical University, 34367 Macka Istanbul, Turkey \\ ${ }^{b}$ Department of Industrial Engineering, Istanbul Technical University, 34367 Macka Istanbul, Turkey
}

Received 05 December 2012; accepted 25 August 2013

\begin{abstract}
Innovation is the way of transforming the resources of a company through the creativity of people into new resources and wealth. Innovation investments are essential instruments in a company's competitive productivity and profitability strategy. Evaluation of innovation investments is a multicriteria decision making problem with many conflicting tangible and intangible criteria. Vague nature of this evaluation requires a fuzzy multicriteria methodology. In this paper we propose a fuzzy multicriteria method to evaluate technological innovation investments using eight different criteria. Fuzzy TOPSIS method is used in this evaluation and a sensitivity analysis is given.
\end{abstract}

Keywords: innovation, fuzzy sets, multicriteria evaluation, investment, TOPSIS.

JEL Classification: C2, E22, O39.

\section{Introduction}

For any organization, innovation represents not only the opportunity to grow and survive but also the opportunity to significantly influence the direction of the industry. Innovation can be defined as the application of new ideas to the products, processes, or other aspects of the activities of a firm that lead to increased value. Research and innovation are keys to achieving economic growth and increased overall welfare. Innovation is the successful exploitation of ideas and it reflects the ability of firms, government and the research base to bring together knowledge, ideas, skills and market awareness into new products or processes that better meet consumer and societal needs, and so result in economic impacts.

A critical component of many firms' investment policies is a strategy for the adoption of technological innovations. Generally, firms follow different strategies: some adopt new technologies when they are first available while others postpone the adoption decision

Corresponding author Asli Suder

E-mail: suder@itu.edu.tr 
until the technology is improved. Some firms will adopt every technological improvement while others bypass the innovation altogether. To measure the economic impacts of investment innovation, overall economic impacts, innovation outcomes and outputs, knowledge generation, and investment in the research base and innovation are required (Grenadier, Weiss 1997).

One of the main elements that determine economic growth nowadays is the new technologies diffusion to firms. Research and development alone is not yet sufficient for technical progress since technological innovations yield no benefits until they are employed. In order to design policy instruments that enhance firm investments in new technologies, it is important to investigate in what circumstances firms are willing to adopt new technologies, and to identify the reasons that make the firm refrain from adoption. At the firm level it can be argued that one of the most crucial decisions is that of investing in new or improved equipment and facilities (Huisman, Kort 2003).

Seven innovation rules are known to be exerting strong leadership on the innovation strategy and portfolio decisions, integrating innovation into the company's basic business mentality, aligning the amount and type of innovation to the company's business, managing the natural tension between creativity and value capture, neutralizing organizational antibodies, recognizing that the basic unit of innovation is a network that includes people and knowledge both inside and outside the organization, and creating the right metrics and rewards for innovation. (Davila et al. 2006)

The Innovation Matrix highlights the fact that not all innovations are created equal. Three types of innovation exist: incremental, semi-radical, and radical. Achieving radical or semi-radical innovation requires a different mix of business model and technology change than incremental innovation. As we will discuss later, creating a portfolio of incremental, semi-radical, and radical innovation is essential to sustained innovation and growth. As with a financial investment portfolio, getting out of the balance decreases the return on investment and increases vulnerability. The senior management team bears the responsibility for creating a balanced portfolio of incremental, semi-radical, and radical innovations and for creating the appropriate business model and technological alternatives. An innovation matrix is given in Figure 1 (Davila et al. 2006).

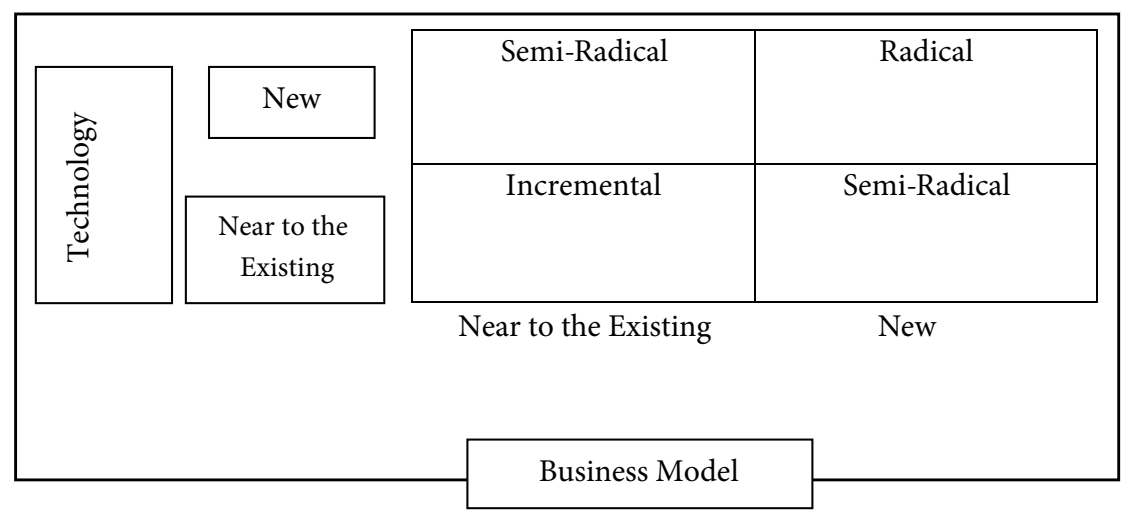

Fig. 1. Innovation matrix 
The importance of innovation is increasing significantly and innovativeness has become a major factor in influencing strategic planning. It has been acknowledged that innovation leads to wealth creation. Many organizations are adopting measures to strengthen their ability to innovate. Competition combined with strong demand is a major driver of innovation. Intensity of competition is the determinant of innovation and productivity. Innovation includes new processes, business systems and new methods of management, which have a significant impact on productivity and growth.

Humans are unsuccessful in making quantitative predictions, whereas they are comparatively efficient in qualitative forecasting. Further, humans are more prone to interference from biasing tendencies if they are forced to provide numerical estimates since the elicitation of numerical estimates forces an individual to operate in a mode which requires more mental effort than that required for less precise verbal statements. Since fuzzy linguistic models permit the translation of verbal expressions into numerical ones, thereby dealing quantitatively with imprecision in the expression of the importance of each criterion, some multi-attribute methods based on fuzzy relations are used. Applications of fuzzy sets within the field of decision-making have, for the most part, consisted of extensions or fuzzifications of the classical theories of decision-making. While decision-making under conditions of risk and uncertainty have been modeled by probabilistic decision theories and by game theories, fuzzy decision theories attempt to deal with the vagueness or fuzziness inherent in subjective or imprecise determinations of preferences, constraints, and goals (Yager 1982).

This paper aims at comparing technological innovation investments using fuzzy TOPSIS. To the best knowledge of the authors, fuzzy TOPSIS has not yet been applied to this kind of problem.

The rest of this paper is organized as follows. Section 1 gives the details of innovation investments. Section 2 presents a literature review on innovation investments. Section 3 includes the evaluation criteria for the selection problem among innovation investments. Section 4 gives the steps of fuzzy TOPSIS and a literature review on it. Section 5 includes the application of fuzzy TOPSIS to the multicriteria evaluation of technological innovation investments. Finally the last Section gives the conclusions.

\section{Technological innovation investments}

The amount of technology innovation depends to a large extent upon the current capabilities that the company has internally or can access through its innovation network. A company that has traditionally competed on its marketing skills and incremental technology improvements will have a tough time suddenly including a semi-radical technology dimension to its strategy. As the world becomes more technologically advanced, the life of a product will become shorter and shorter (Davila et al. 2006).

Attractiveness for innovation requires close co-ordination/integration of innovation policy and inward investment promotion policy. Technological change and innovation have traditionally been seen as a linear process of diffusion of knowledge, from basic, to applied research, to development and commercialization of product and process improvements. More realistically, it is recognized that there is a high degree of feedback along this spectrum, involving interaction and relationships between many different parties (Lester 2001). 
Competition and collaboration of firms helps themselves to develop their ability to effectively pursue technological innovations. As technological battles have intensified and technologies have become more complex, firms face numerous challenges such as raising R\&D costs, high risk and uncertainty in technological development, as well as a lack of resources to pursue large-scale innovation projects (BarNir, Smith 2002).

Sometimes new technologies are a major part of an innovation, and they stand out and garner significant attention. Other times, the new technologies are hidden out of sight and can only be seen by the technical people servicing them. Either way, technology change can fuel innovations in three distinct ways; namely in product and service offerings, process technologies, and enabling technologies.

Technological innovation drives the performance of the products or services that the company offers. Changes in the technologies that are integral parts of product manufacturing and service delivery can result in better, faster, and less expensive products and services. Companies continually strive to make changes to the technologies that could reduce cost and improve the quality of existing products or services. Technology enables a company to execute the strategy much faster and leverage time as a source of competitive advantage. Technological innovation investments have a significant contribution for economic welfare of countries.

\section{Literature review}

Research on innovation investments is an interesting area which many researchers have recently focused on. Below, a summary of the studies on innovation investments is given.

Grenadier and Weiss (1997) develop a model of the optimal investment strategy for a firm confronted with a sequence of technological innovations. They incorporate many of the most important characteristics of real-world technology markets. For example, they permit innovations to be stochastic in their arrival times and their profitability. They also incorporate learning so that firms adopting current innovations become better able to benefit from future innovations. The model yields four distinct investment strategies. The model is then used to predict actual firm policy. These implications are discussed and compared with observed firm behavior. Reiss (1998) applies option-based valuation to determine whether and when a firm should patent and adopt an innovation if the arrival time of competitors is stochastic. Four distinct strategies are derived: Apply for a patent without introducing the new technology right away, patent the innovation and invest immediately, initiate the new project without patent protection, or defer the decision. It is shown how competition and the patent fee level affect the strategy to be pursued and the maximum fixed R\&D expenditures. Maurer (1999) extends previous works on predatory behavior against financially constrained firms to include innovation and product market competition. He shows that the pattern of strategic interaction between competing firms determines behavioral changes coming from financial constraints. Both leveraged and unleveraged firms react to financial constraints. The theory is used to explain recent empirical findings concerning the interaction of capital market imperfections and market structure.

Koski (2003) focuses on the creation of a model that will simulate the venture capitalist's perception regarding the success potential of a venture and the venture capital investment. 
It presents the basis for the utilization of fuzzy set theory and fuzzy logic in order to create the model. Also presented in the study are the empirical results needed to create the membership functions needed to build the model in practice. As the result of a pilot field study, preliminary conclusions can be drawn about how Finnish venture capitalists weight different estimated success factors in comparison to previous studies, usually made in the USA and Europe. Huisman and Kort (2003) determine the optimal timing of technology investment of a single firm in a duopoly framework. As time passes different technologies are invented which after sometime become available for the firm to adopt. The question is not only when a firm should invest but also which technology should be adopted. For different scenarios the optimal technology investment decision is determined. Wickelgren (2004) analyzes the innovation incentives under monopoly and duopoly provision of horizontally differentiated products purchased via bilateral negotiations, integrating the market structure and innovation literature with the holdup literature. He shows that competition can improve local incentives for non-contractible investment.

DeMarzo et al. (2007) investigate why new, high-risk technologies can attract excessive and often unprofitable investment. They develop an equilibrium model in which rational, risk-averse agents overinvest in a risky technology, possibly to the point that its expected return is negative. Overinvestment results from relative wealth concerns which arise endogenously from the imperfect tradability of future endowments. Overinvestment increases with the risk of the technology. Hence, their model can explain why new and risky technological innovations may promote investment bubbles. Cumming (2007) analyses 280 Australian venture capital and private equity funds and their investments in 845 entrepreneurial firms over the period 1982-2005. He focuses the analysis on the Innovation Investment Fund (IIF) governmental program, first introduced in 1997. In order to highlight the unique aspects of the IIF, he compares the properties of the Australian IIF program with government venture capital programs in Canada, the UK and the US. Allred and Park (2007) test the influence of a country's patent rights and changes in them on firm-level investment in innovation. Data for 706 firms competing in ten manufacturing industries across 29 countries are gathered and analyzed. Even after controlling for various firm, industry, and national factors, there is a strong positive influence of patent rights and changes in patent rights on a firm's propensity to invest in innovation. In addition, they consider the sensitivity of this result to alternative measures of patent and other intellectual property protection. They also find that the influence of patent rights on firm-level innovation varies across industries for example, the impact appears greatest in the scientific instruments and industrial chemicals industries.

Peneder (2008) reviews the major finance-related causes of private under-investment in innovation and the consequent alternative choices for public policy. The focus is on (i) incentive-based arguments that address the problem of limited appropriability of new knowledge, and (ii) the lacking access to external sources of finance caused by imperfections in the capital market. Drawing a policy mind map, which aims to enhance the mutual awareness and coordination of policy makers at the crossroads of technology and corporate finance, the paper, is organized along the following chain of thought: (i) causes and rationales, (ii) aims and targets, (iii) critical constraints, and (iv) the main finance-related instruments of innovation policy. Andersson et al. (2009) investigate the economic effects of the decentralization policy on the 
level of productivity and innovation and their spatial distribution in the national economy. They find important and significant effects of this investment policy upon economic output and the locus of knowledge production, suggesting that the decentralization has affected regional development through local innovation and increased creativity. Their evidence also suggests that aggregate productivity was increased by the deliberate policy of decentralization. Girma et al. (2009) investigate whether inward foreign direct investment, either at the firm or industry level, has any impact on product innovation by Chinese state-owned enterprises. They use a comprehensive firm-level panel data set of some 20,000 SOEs during 1999-2005. Their results show that foreign capital participation at the firm level is associated with higher innovative activity. Inward FDI in the sector, by contrast, has a negative effect on innovative activity in SOEs on average. However, there is a positive effect of sector-level FDI on SOEs that export, invest in human capital, or undertake R\&D.

Ghosal and Nair-Reichert (2009) examine the impact of investments in modernization and innovation on productivity in a sample of firms in the global pulp and paper industry. The firms that implemented a greater number of investment transactions in modernization achieved higher productivity, and these estimated quantitative effects are greater than the impact of standard innovation variables such as patents and $R \& D$. Investment transactions in the information technology and digital monitoring devices imparted a particularly noticeable boost to productivity. Liao and Rice (2010) develop a mediated model by which they examine the impact of innovation on firm performance mediated through a firm's market engagement and transformation strategies using a sample of 449 Australian manufacturing companies from the Business Longitudinal Survey from the Australian Bureau of Statistics. The paper finds that organizational performance is driven by innovation only when mediated through these transformation outcomes. The results contribute to the innovation literature in finding that innovation related activities can only drive a firm's competitive advantage when they occur concomitantly with actual changes in the market position and offerings of firms. Iwaisako et al. (2011) construct a North-South quality-ladder model in which foreign direct investment (FDI) is determined by the endogenous location choice of firms, and examines analytically how strengthening patent protection in the South affects welfare in the South. Strengthening patent protection increases the South's welfare by enhancing innovation and FDI, but it also allows the firms with patents to charge higher prices for their goods, which decreases welfare. However, the model shows that the former positive welfare effect outweighs the latter negative effect.

Paunov (2012) provides first quantitative evidence on the impact of the current global crisis on firms' innovation profiles by exploring original firm-level data for eight Latin American countries in 2008-2009. While innovation performance did not decrease, one in four firms stopped innovation projects due to the global crisis. Rising financing constraints and the negative demand shock brought by the economic crisis likely had an impact on firms' decisions to abandon innovation projects. Probit regression results show that firms with access to public funding were less likely to abandon these investment projects. This highlights the potentially significant role of public funding in stabilizing innovation investments during recession periods. Wang (2012) outlines the important factors that multinational corporations must address to gain competitive advantages in Chinas e-commerce sector. The author un- 
derscores the importance of local knowledge for firm performance and success. Foreign firms must improve their understanding of and ability to adapt to local cultural, social, economic, and political environments.

Fu et al. (2013) study the performance evaluation of scientific innovation team in universities based on the gray fuzzy theory. A more comprehensive set of indicator system is built to conduct a comprehensive evaluation. Lu et al. (2013) address network relationship problems using the novel method of new fuzzy hybrid multiple criteria decision-making, including fuzzy DEMATEL (fuzzy decision-making trial and evaluation laboratory), fuzzy DANP (fuzzy DEMATEL-based ANP) and VIKOR, to examine the interdependent and feedback problems among various dimensions/criteria of environmental strategic orientations. Liu et al. (2014) provide the basis on quantity for evaluation of innovation talent at universities under the environment of building innovation society in their country. They draw on existing research results to build the evaluation indicator system of innovation talents training at universities from the perspective of input, conversion, and output and applies AHP-fuzzy comprehensive evaluation model to evaluate the indicator system. Wang et al. (2014) analyze the models on technical innovation for the petrol equipment manufacturing enterprises, including motive force and impetus, to establish comprehensive evaluation index system about technical innovation.

\section{Evaluation criteria}

In our study, we will consider the following criteria for the evaluation of technological innovation investments (Science and Innovation Investment Framework 2004). These seven criteria are used for the ranking of six technological innovation investment alternatives based on fuzzy TOPSIS.

Knowledge exchange efficiency (KEE): it depends on ease of co-operation/collaboration and transit of information flows. Government policies that aim at improving the flows of knowledge between the research base and industry are reflected in measurement of the knowledge exchange efficiency.

Demand for innovation investments (DII): it is the result of private and public sector attitudes and capacities to develop innovation outputs.

Framework conditions (FC): it includes attractiveness of investment, financial sustainability and standards. Government policies on the intellectual property framework and financial sustainability aim to create the right conditions for research and innovation.

Knowledge generation $(K G)$ : it produces human capital and stock of publicly available knowledge.

Increased productivity (IP): An increase in productivity is expected from innovation investments.

Increased welfare (IW): Government's aims on improving welfare through research and innovation.

Innovation technological outcomes (ITO): it causes technological development and provides a competitive advantage. 
Investment in the research base (IRB): Government investment in $\mathrm{R} \& \mathrm{D}$ and innovation is captured by the investment in the research base and innovation. Expenditure on $R \& D$ is a must for a successful innovation. If too little is spent on $\mathrm{R} \& \mathrm{D}$, the right conditions for research and innovation may not be created.

\section{Fuzzy multicriteria evaluation of innovation investments using fuzzy TOPSIS}

TOPSIS, one of the classical multi-criteria decision making methods was developed by Hwang and Yoon (1981). It is based on the concept that the chosen alternative should have the shortest distance from the positive ideal solution (PIS) and the farthest from the negative ideal solution (NIS). TOPSIS also provides an easily understandable and programmable calculation procedure. It has the ability of taking various criteria with different units into account simultaneously (Ekmekçioglu et al. 2010). By using the vector normalization, the method chooses the alternative with the largest value of $C_{i}^{*}$ :

$$
C_{i}^{*}=\frac{\sqrt{\sum_{j=1}^{n}\left(w_{j} \frac{x_{i j}}{\sqrt{\sum_{i=1}^{m} x_{i j}^{2}}}-v_{j}^{-}\right)^{2}}}{\sqrt{\sum_{j=1}^{n}\left(w_{j} \frac{x_{i j}}{\sqrt{\sum_{i=1}^{m} x_{i j}^{2}}}-v_{j}^{*}+\left(\sum_{j=1}^{n}\left(w_{j} \frac{x_{i j}}{\sqrt{\sum_{i=1}^{m} x_{i j}^{2}}}-v_{j}^{-}\right)^{2}\right.\right.}} ;
$$

or it chooses the alternative with the least value of $C_{i}^{-}$:

$$
C_{i}^{-}=\frac{\sqrt{\sum_{j=1}^{n}\left(w_{j} \frac{x_{i j}}{\sqrt{\sum_{i=1}^{m} x_{i j}^{2}}}-v_{j}^{*}\right)^{2}}}{\sqrt{\sum_{j=1}^{n}\left(w_{j} \frac{x_{i j}}{\sqrt{\sum_{i=1}^{m} x_{i j}^{2}}}-v_{j}^{*}+\sqrt{\sum_{j=1}^{n}\left(w_{j} \frac{x_{i j}}{\sqrt{\sum_{i=1}^{m} x_{i j}^{2}}}-v_{j}^{-}\right.}\right)^{2}}},
$$

where $i(i=1, \ldots, \mathrm{m})$ and $j(j=1, \ldots, \mathrm{n})$ indicate alternative and attribute numbers respectively; $w_{j}$ is the weight of the $j$ th attribute; $x_{i j}$ is the attribute rating for $i$ th alternative's $j$ th attribute; 
$v_{j}^{*}$ is the positive-ideal value for $j$ th attribute, where it is a maximum for benefit attributes and a minimum for cost attributes; $v_{j}^{-}$is the negative-ideal value for the $j$ th attribute, where it is a minimum for benefit attributes and a maximum for cost attributes. We use fuzzy distance measurements in fuzzy TOPSIS. Besides, type-1 fuzzy membership functions are used this method.

In the following the steps of fuzzy TOPSIS method are given (Yoon, Hwang 1995).

Step 1. Normalize the Decision Matrix. The decision matrix must first be normalized so that the elements are unit-free. To avoid the complicated normalization formula used in classical TOPSIS, we use linear scale transformation as follows:

$$
r_{i j}=\left\{\begin{array}{l}
\mathrm{x}_{\mathrm{ij}} / \mathrm{x}_{\mathrm{j}^{\star}}, \forall_{\mathrm{j}}, \mathrm{x}_{\mathrm{j}} \text { is a benefit attribute; } \\
\mathrm{x}_{\mathrm{j}-} / \mathrm{xij}, \forall_{\mathrm{j}}, \mathrm{x}_{\mathrm{j}} \text { is a cost attribute. }
\end{array}\right.
$$

By applying Eq. (1), we can rewrite the decision matrix as:

$$
\mathrm{D}^{\prime}=\underset{\mathrm{A}_{1}}{\mathrm{~A}_{1}}\left[\begin{array}{ccccc}
\mathrm{x}_{1} & & \mathrm{x}_{\mathrm{j}} & & \mathrm{x}_{\mathrm{n}} \\
\mathrm{r}_{11} & \cdots & \mathrm{r}_{1 j} & \cdots & \mathrm{r}_{1 \mathrm{n}} \\
\vdots & & \vdots & & \vdots \\
\mathrm{A}_{\mathrm{m}} & \cdots & \mathrm{r}_{\mathrm{ij}} & \cdots & \mathrm{r}_{\mathrm{in}} \\
\vdots & & \vdots & & \vdots \\
\mathrm{r}_{\mathrm{m} 1} & \cdots & \mathrm{r}_{\mathrm{mj}} & \cdots & \mathrm{r}_{\mathrm{mn}}
\end{array}\right] .
$$

When $\mathrm{x}_{i j}$ is crisp, its corresponding $r_{i j}$ must be crisp; when $x_{i j}$ is fuzzy, its corresponding $r_{i j}$ must be fuzzy. Eq. (1) is then replaced by the following fuzzy operations: Let $x_{i j}=\left(a_{i j}, b_{i j}\right.$, $\left.c_{i j}, d_{i j}\right), x_{j}^{*}=\left(a_{j}^{*}, b_{j}^{*}, c_{j}^{*}, d_{j}^{*}\right)$ and $x_{j}^{-}=\left(a_{j}^{-}, b_{j}^{-}, c_{j}^{-}, d_{j}^{-}\right)$then we have:

$$
r_{i j}=\left\{\begin{array}{l}
\mathrm{x}_{\mathrm{ij}}(:) \mathrm{x}_{\mathrm{j}}^{*}=\left(\frac{\mathrm{a}_{\mathrm{ij}}}{\mathrm{d}_{\mathrm{j}}{ }^{*}}, \frac{b_{\mathrm{ij}}}{\mathrm{c}_{\mathrm{j}}^{*}}, \frac{\mathrm{c}_{\mathrm{ij}}}{\mathrm{b}_{\mathrm{j}}{ }^{*}}, \frac{\mathrm{d}_{\mathrm{ij}}}{\mathrm{a}_{\mathrm{j}}{ }^{*}}\right), \mathrm{x}_{\mathrm{j}} \text { is a benefit attribute; } \\
\mathrm{x}_{\mathrm{j}}^{-}(:) \mathrm{x}_{\mathrm{ij}}=\left(\frac{\mathrm{a}_{\mathrm{i}}^{-}}{\mathrm{d}_{\mathrm{ij}}}, \frac{b_{i}^{-}}{\mathrm{c}_{i j}}, \frac{\mathrm{c}_{\mathrm{i}}^{-}}{\mathrm{b}_{\mathrm{ij}}}, \frac{\mathrm{d}_{\mathrm{i}}^{-}}{\mathrm{a}_{\mathrm{ij}}}\right), \mathrm{x}_{\mathrm{j}} \text { is a cost attribute. }
\end{array}\right.
$$

Lets give a numerical illustration for Eq. (5). Assume that $x_{i j}=(2,7,9,14)$ and $x_{j}^{*}=(5$, $10,16,18)$ where the attribute is a benefit one, then $0.1111,0.4375,0.9000,2.8000)$. If the attribute is a cost one and $x_{i j}=(2,7,9,14)$ and $x_{j}^{-}=(1,3,5,9)$ then.

Step 2. Obtain the Weighted Normalized Decision Matrix. This matrix is obtained using:

$$
v_{i j}=r_{i j} w_{j}, \forall_{j}, j \text {. }
$$

When both $r_{i j}$ and $w_{j}$ are crisp, $v_{i j}$ is crisp; while when either $r_{i j}$ or $w_{j}$, (or both) are fuzzy, Eq. (6) may be replaced by the following fuzzy operations:

$$
\begin{gathered}
\mathrm{v}_{\mathrm{ij}=} \mathrm{r}_{\mathrm{ij}}(.) \mathrm{w}_{\mathrm{j}}^{*}=\left(\frac{\mathrm{a}_{\mathrm{ij}}}{\mathrm{d}_{\mathrm{j}}{ }^{*}} \alpha_{j}, \frac{b_{\mathrm{ij}}}{\mathrm{c}_{\mathrm{j}}{ }^{*}} \beta_{j}, \frac{\mathrm{c}_{\mathrm{ij}}}{\mathrm{b}_{\mathrm{j}}{ }^{*}} \gamma_{j}, \frac{\mathrm{d}_{\mathrm{ij}}}{\mathrm{a}_{\mathrm{j}}{ }^{*}} \delta_{j}\right) ; \\
\mathrm{v}_{\mathrm{ij}=} \mathrm{r}_{\mathrm{ij}}(.) \mathrm{w}_{\mathrm{j}}^{*}=\left(\frac{\mathrm{a}_{\mathrm{i}}^{-}}{\mathrm{d}_{\mathrm{ij}}} \alpha_{j}, \frac{b_{i}^{-}}{\mathrm{c}_{i j}} \beta_{j}, \frac{\mathrm{c}_{\mathrm{i}}^{-}}{\mathrm{b}_{\mathrm{ij}}} \gamma_{j}, \frac{\mathrm{d}_{\mathrm{i}}^{-}}{\mathrm{a}_{\mathrm{ij}}} \delta_{j}\right) .
\end{gathered}
$$


Eq. (7) is used when the jth attribute is a benefit attribute. Eq. (8) is used when the $j$ th attribute is a cost attribute. The result of Eqs (7) and (8) can be summarized as:

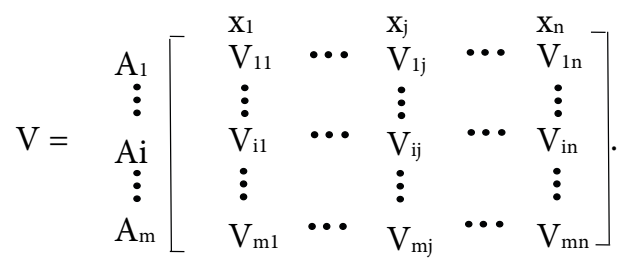

Step 3. Obtain the Positive Ideal Solution (PIS), $A^{*}$, and the Negative Ideal Solution (NIS). PIS and NIS are defined as:

$$
\begin{aligned}
& A^{*}=\left[\mathrm{v}_{1}^{*}, \ldots, \mathrm{v}_{\mathrm{n}}{ }^{*}\right] ; \\
& \mathrm{A}^{-}=\left[\mathrm{v}_{1}^{-}, \ldots, \mathrm{v}_{\mathrm{n}}{ }^{-}\right],
\end{aligned}
$$

where $v_{j}^{*}=\max _{i} v_{i j}$ and $v_{j}^{-}=\min _{i} v_{i j}$.

Step 4. Obtain the Seperation Measures $S_{i}^{*}$ and $S_{i}^{-}$. In the classical case, seperation measures are defined as:

and

$$
\mathrm{S}_{\mathrm{i}}^{*}=\sum_{j=1}^{n} \mathrm{D}_{\mathrm{ij}}{ }^{*}, \mathrm{i}=1, \ldots, \mathrm{m} .
$$

$$
\mathrm{S}_{\mathrm{i}}^{-}=\sum_{j=1}^{n} \mathrm{D}_{\mathrm{ij}}{ }^{-}, \mathrm{i}=1, \ldots, \mathrm{m} .
$$

For crisp data, the difference measures $D_{i j}{ }^{*}$ and $D_{i j}{ }^{-}$are given as:

$$
\begin{aligned}
& \operatorname{Dij}^{*}=\left|v i j-v j^{*}\right| ; \\
& \text { Dij- }=|v i j-v j-| .
\end{aligned}
$$

Step 5. Compute the Relative Closeness to Ideals. This index is used to combine $S_{i}^{*}$ and $S_{i}^{-}$indices calculated in Step 4. Since $S_{i}^{*}$ and $S_{i}^{-}$are crisp numbers, they can be combined:

$$
\mathrm{C}_{\mathrm{i}}=\mathrm{S}_{\mathrm{i}}^{-} /\left(\mathrm{S}_{\mathrm{i}}^{*}+\mathrm{S}_{\mathrm{i}}^{-}\right) \text {. }
$$

The alternatives are ranked in descending order of the $C_{i}$ index.

Fuzzy TOPSIS has been recently used in the analysis of various problems. Yong (2006) used fuzzy TOPSIS for plant location selection. Kahraman et al. (2007) utilized fuzzy TOPSIS for industrial robotic system selection. There are various fuzzy TOPSIS studies in various areas as clean agent selection (Aiello 2009), firms' competence evaluation (Amiri et al. 2009), assessing thermal-energy storage in concentrated solar power (CSP) systems (Cavallaro 2010), development of a quick credibility scoring decision support system (Ic, Yurdakul 2010), personnel selection (Kelemenis, Askounis 2010), supplier selection (Roghanian et al. 2010), assessment of traffic police centers performance (Sadi-Nezhad, Damghani 2010), evaluating the competitive advantages of shopping websites (Sun, Lin 2009), virtual enterprise partner selection (Ye 2010), etc. The publications including fuzzy TOPSIS method have significantly increased in recent years. Ekmekçioglu et al. (2010) used a modified fuzzy TOPSIS to select municipal solid waste disposal method and site. Kutlu and Ekmekçioglu (2010) used fuzzy TOPSIS integrated with fuzzy AHP to propose a new FMEA “failure modes \& effects analysis" which 
overcomes the shortcomings of traditional FMEA. Kaya and Kahraman (2011) proposed a modified fuzzy TOPSIS for selection of the best energy technology alternative. Paksoy et al. (2012) develop the organization strategy of distribution channel management using fuzzy AHP and hierarchical fuzzy TOPSIS for an edible-vegetable oils manufacturer firm operating in Turkey. Sun (2012) develops an evaluation model based on fuzzy AHP and fuzzy TOPSIS to help the industrial practitioners for the performance evaluation in a fuzzy environment.

\section{A numerical application}

An international company that builds on the parent corporation's technology and R\&D aims at investing in new possible innovation alternatives which include innovation for automotive industry, innovation for military power, innovation for healthcare, innovation for environmental protection, innovation for agriculture, and innovation for education. Top management of this company will select one of these innovation opportunities based on the following seven criteria: Knowledge exchange efficiency (KEE), Demand for innovation investments (DII), Framework conditions (FC), Knowledge generation (KG), Increased productivity (IP), Increased welfare (IW), Innovation technological outcomes (ITO), and Investment in the research base (IRB). In the evaluation of the alternatives, the scale in Table 1 is used. Figure 2 illustrates the triangular fuzzy conversion scale in Table 1.

Table 1. Triangular fuzzy conversion scale for the alternatives

\begin{tabular}{lc}
\hline \multicolumn{1}{c}{ Linguistic scale for criteria and alternatives } & Triangular fuzzy scale \\
\hline Extremely low importance (EL) & $(1,1,2)$ \\
\hline Very low importance (VL) & $(1,2,3)$ \\
\hline Low importance (L) & $(2,3,4)$ \\
\hline Medium importance (M) & $(3,4,5)$ \\
\hline High importance (H) & $(4,5,6)$ \\
\hline Very high importance (VH) & $(5,6,7)$ \\
\hline Extremely high importance (EH) & $(6,7,7)$ \\
\hline
\end{tabular}

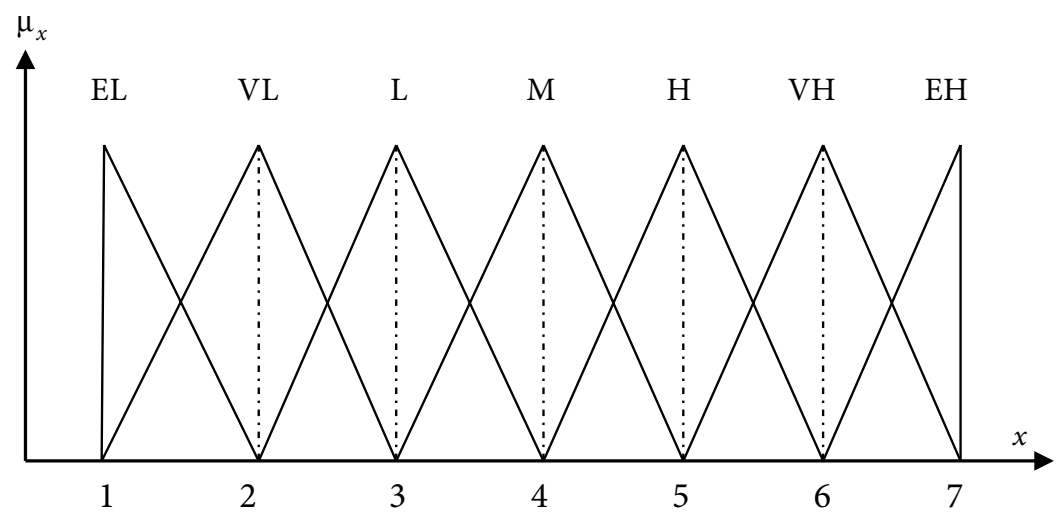

Fig. 2. Linguistic scale 
Table 2 presents the decision matrix with linguistic evaluations of six alternatives with respect to eight criteria.

Table 2. Decision matrix with linguistic evaluations

\begin{tabular}{lcccccccc}
\hline \multirow{2}{*}{ ALTERNATIVES } & \multicolumn{7}{c}{ CRITERIA } \\
\cline { 2 - 9 } & KEE & DII & FC & KG & IP & IW & ITO & IRB \\
\hline $\begin{array}{l}\text { Innovation for automotive } \\
\text { industry }\end{array}$ & $\mathrm{VH}$ & $\mathrm{EH}$ & $\mathrm{VH}$ & $\mathrm{M}$ & $\mathrm{VH}$ & $\mathrm{H}$ & $\mathrm{H}$ & $\mathrm{VH}$ \\
\hline Innovation for military power & $\mathrm{VL}$ & $\mathrm{H}$ & $\mathrm{VH}$ & $\mathrm{H}$ & $\mathrm{VL}$ & $\mathrm{H}$ & $\mathrm{VH}$ & $\mathrm{H}$ \\
\hline Innovation for healthcare & $\mathrm{H}$ & $\mathrm{VH}$ & $\mathrm{H}$ & $\mathrm{VH}$ & $\mathrm{H}$ & $\mathrm{H}$ & $\mathrm{VH}$ & $\mathrm{H}$ \\
\hline $\begin{array}{l}\text { Innovation for environmental } \\
\text { protection }\end{array}$ & $\mathrm{VL}$ & $\mathrm{H}$ & $\mathrm{M}$ & $\mathrm{L}$ & $\mathrm{L}$ & $\mathrm{M}$ & $\mathrm{H}$ & $\mathrm{L}$ \\
\hline Innovation for agriculture & $\mathrm{H}$ & $\mathrm{H}$ & $\mathrm{M}$ & $\mathrm{L}$ & $\mathrm{L}$ & $\mathrm{M}$ & $\mathrm{M}$ & $\mathrm{M}$ \\
\hline Innovation for education & $\mathrm{VH}$ & $\mathrm{H}$ & $\mathrm{L}$ & $\mathrm{L}$ & $\mathrm{VH}$ & $\mathrm{M}$ & $\mathrm{L}$ & $\mathrm{M}$ \\
\hline
\end{tabular}

Table 3 converts the decision matrix in Table 2 to the decision matrix with numerical evaluations.

Table 3. Decision matrix with numerical evaluations

\begin{tabular}{lcccccccc}
\hline \multirow{2}{*}{ ALTERNATIVES } & \multicolumn{7}{c}{ CRITERIA } \\
\cline { 2 - 8 } & KEE & DII & FC & KG & IP & IW & ITO & IRB \\
\hline $\begin{array}{l}\text { Innovation for } \\
\text { automotive industry }\end{array}$ & $(5,6,7)$ & $(6,7,7)$ & $(5,6,7)$ & $(3,4,5)$ & $(5,6,7)$ & $(4,5,6)$ & $(4,5,6)$ & $(5,6,7)$ \\
\hline $\begin{array}{l}\text { Innovation for } \\
\text { military power }\end{array}$ & $(1,2,3)$ & $(4,5,6)$ & $(5,6,7)$ & $(4,5,6)$ & $(1,2,3)$ & $(4,5,6)$ & $(5,6,7)$ & $(4,5,6)$ \\
\hline $\begin{array}{l}\text { Innovation for } \\
\text { healthcare }\end{array}$ & $(4,5,6)$ & $(5,6,7)$ & $(4,5,6)$ & $(5,6,7)$ & $(4,5,6)$ & $(4,5,6)$ & $(5,6,7)$ & $(4,5,6)$ \\
\hline $\begin{array}{l}\text { Innovation for } \\
\text { environmental } \\
\text { protection }\end{array}$ & $(1,2,3)$ & $(4,5,6)$ & $(3,4,5)$ & $(2,3,4)$ & $(2,3,4)$ & $(3,4,5)$ & $(4,5,6)$ & $(2,3,4)$ \\
\hline $\begin{array}{l}\text { Innovation for } \\
\text { agriculture }\end{array}$ & $(4,5,6)$ & $(4,5,6)$ & $(3,4,5)$ & $(2,3,4)$ & $(2,3,4)$ & $(3,4,5)$ & $(3,4,5)$ & $(3,4,5)$ \\
\hline $\begin{array}{l}\text { Innovation for } \\
\text { education }\end{array}$ & $(5,6,7)$ & $(4,5,6)$ & $(2,3,4)$ & $(2,3,4)$ & $(5,6,7)$ & $(3,4,5)$ & $(2,3,4)$ & $(3,4,5)$ \\
\hline Criteria weights $(\mathbf{w})$ & $\mathbf{0 . 1}$ & $\mathbf{0 . 1 5}$ & $\mathbf{0 . 1}$ & $\mathbf{0 . 0 5}$ & $\mathbf{0 . 1 5}$ & $\mathbf{0 . 2 5}$ & $\mathbf{0 . 0 5}$ & $\mathbf{0 . 1 5}$ \\
\hline
\end{tabular}

Table 4 shows the normalized decision matrix. Table 5 shows the weighted fuzzy normalized decision matrix. Table 6 presents the distances to positive ideal solutions. Table 7 gives the distances to negative ideal solutions. Table 8 presents similarity coefficients to ideal solutions and ranks of alternatives. 
Table 4. Normalized fuzzy decision matrix

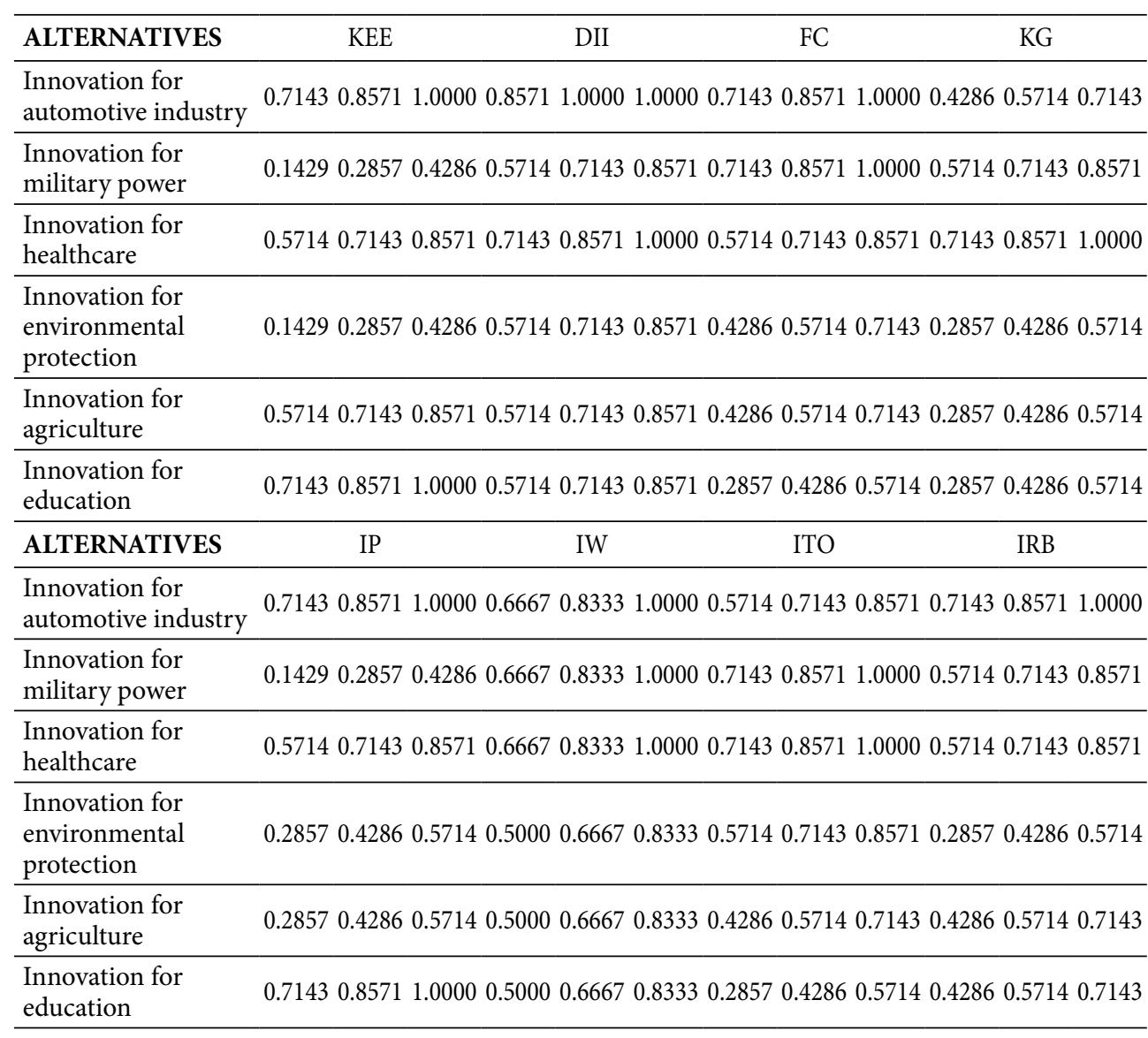

Table 5. Weighted fuzzy normalized decision matrix

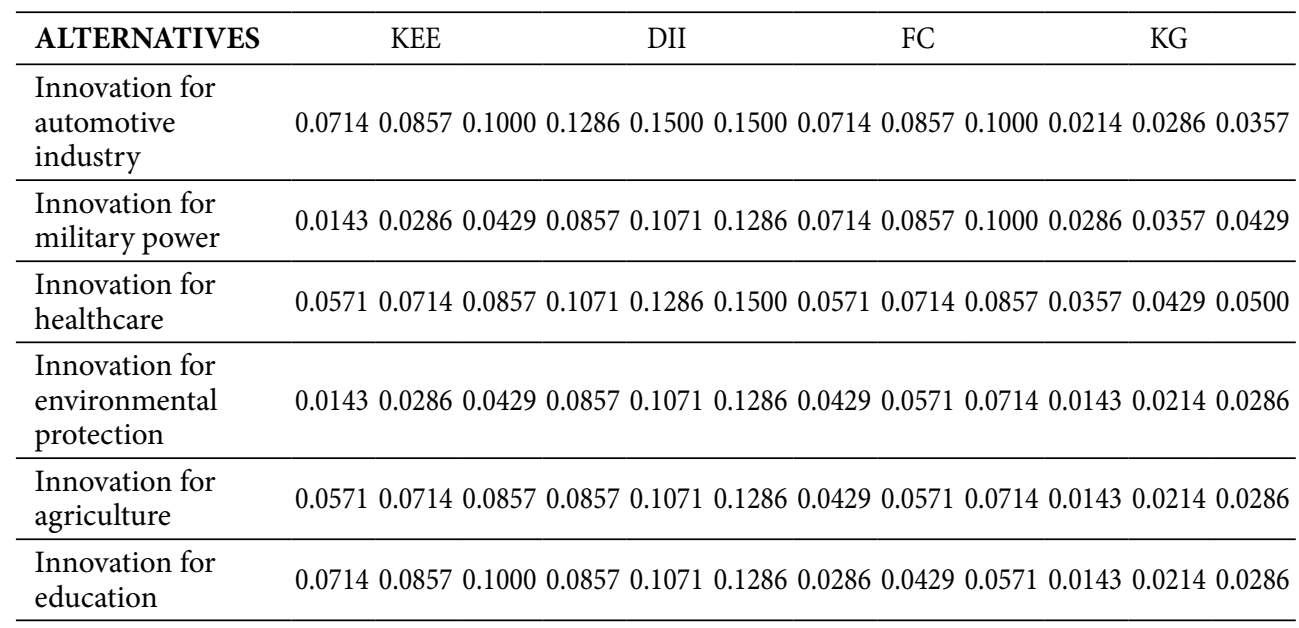


End of Table 5

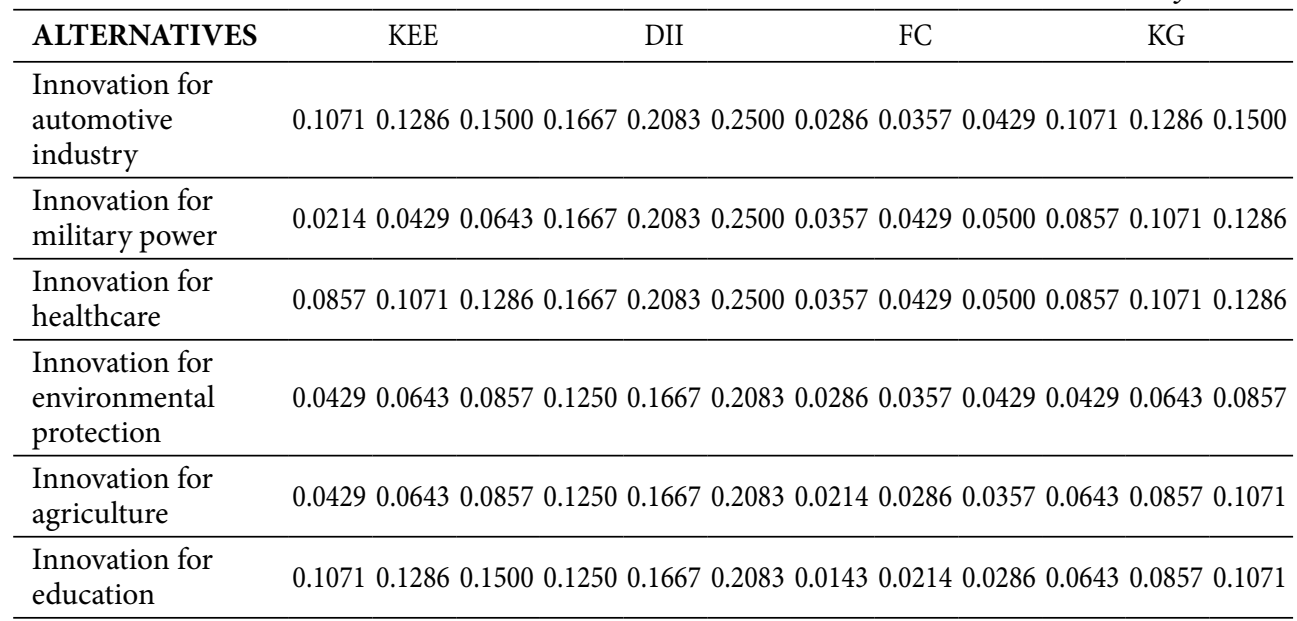

Table 6. Distances to positive ideal solutions

\begin{tabular}{lccccccccc}
\hline ALTERNATIVES & $\mathrm{C} 1$ & $\mathrm{C} 2$ & $\mathrm{C} 3$ & $\mathrm{C} 4$ & $\mathrm{C} 5$ & $\mathrm{C} 6$ & $\mathrm{C} 7$ & $\mathrm{C} 8$ & Total \\
\hline $\begin{array}{l}\text { Innovation for } \\
\text { automotive } \\
\text { industry }\end{array}$ & 0.9144 & 0.8572 & 0.9144 & 0.9714 & 0.8716 & 0.7924 & 0.9643 & 0.8716 & 7.1573 \\
\hline $\begin{array}{l}\text { Innovation for } \\
\text { military power }\end{array}$ & 0.9715 & 0.8930 & 0.9144 & 0.9643 & 0.9573 & 0.7924 & 0.9572 & 0.8930 & 7.3431 \\
\hline $\begin{array}{l}\text { Innovation for } \\
\text { healthcare }\end{array}$ & 0.9286 & 0.8716 & 0.9286 & 0.9572 & 0.8930 & 0.7924 & 0.9572 & 0.8930 & 7.2217 \\
\hline $\begin{array}{l}\text { Innovation for } \\
\text { environmental } \\
\text { protection }\end{array}$ & 0.9715 & 0.8930 & 0.9429 & 0.9786 & 0.9359 & 0.8340 & 0.9643 & 0.9359 & 7.4561 \\
\hline $\begin{array}{l}\text { Innovation for } \\
\text { agriculture }\end{array}$ & 0.9286 & 0.8930 & 0.9429 & 0.9786 & 0.9359 & 0.8340 & 0.9714 & 0.9145 & 7.3990 \\
\hline $\begin{array}{l}\text { Innovation for } \\
\text { education }\end{array}$ & 0.9144 & 0.8930 & 0.9572 & 0.9786 & 0.8716 & 0.8340 & 0.9786 & 0.9145 & 7.3419 \\
\hline
\end{tabular}

Table 7. Distances to negative ideal solutions

\begin{tabular}{lccccccccc}
\hline ALTERNATIVES & KEE & DII & FC & KG & IP & IW & ITO & IRB & Total \\
\hline $\begin{array}{l}\text { Innovation for } \\
\text { automotive industry }\end{array}$ & 0.0865 & 0.1432 & 0.0865 & 0.0292 & 0.1298 & 0.2111 & 0.0362 & 0.1298 & 0.8522 \\
\hline $\begin{array}{l}\text { Innovation for military } \\
\text { power }\end{array}$ & 0.0309 & 0.1086 & 0.0865 & 0.0362 & 0.0463 & 0.2111 & 0.0433 & 0.1086 & 0.6713 \\
\hline Innovation for healthcare & 0.0724 & 0.1298 & 0.0724 & 0.0433 & 0.1086 & 0.2111 & 0.0433 & 0.1086 & 0.7892 \\
\hline $\begin{array}{l}\text { Innovation for } \\
\text { environmental protection }\end{array}$ & 0.0309 & 0.1086 & 0.0583 & 0.0222 & 0.0666 & 0.1701 & 0.0362 & 0.0666 & 0.5595 \\
\hline Innovation for agriculture & 0.0724 & 0.1086 & 0.0583 & 0.0222 & 0.0666 & 0.1701 & 0.0292 & 0.0875 & 0.6148 \\
\hline Innovation for education & 0.0865 & 0.1086 & 0.0444 & 0.0222 & 0.1298 & 0.1701 & 0.0222 & 0.0875 & 0.6712 \\
\hline
\end{tabular}


Table 8. Similarity coefficients to ideal solutions and ranks of alternatives

\begin{tabular}{lcc}
\hline \multicolumn{1}{c}{ ALTERNATIVES } & Similarity coefficients & Rank \\
\hline Innovation for automotive industry & 0.1064 & 1 \\
\hline Innovation for military power & 0.0838 & 3 \\
\hline Innovation for healthcare & 0.0985 & 4 \\
\hline Innovation for environmental protection & 0.0698 & 6 \\
\hline Innovation for agriculture & 0.0767 & 5 \\
\hline Innovation for education & 0.0838 & 2 \\
\hline
\end{tabular}

The obtained results indicate that, for the considered company, innovation investments for automotive industry are the most attractive alternative. The second and third ranks belong to innovation investments for education and for military power, respectively. The last rank belongs to innovation for environmental protection.

\section{Sensitivity analysis}

In this analysis we want to observe the effects of changing criteria weights on the rank of alternatives. We examined four different sets of criteria weights as given in Table 9.

Table 9. Cases for sensitivity analysis

\begin{tabular}{cccccc}
\hline Criteria & Present case & Case 1 & Case 2 & Case 3 & Case 4 \\
\hline KEE & 0.10 & 0.10 & 0.08 & 0.01 & 0.44 \\
\hline DII & 0.15 & 0.14 & 0.05 & 0.05 & 0.10 \\
\hline FC & 0.10 & 0.08 & 0.08 & 0.30 & 0.005 \\
\hline KG & 0.05 & 0.06 & 0.15 & 0.15 & 0.005 \\
\hline IP & 0.15 & 0.17 & 0.10 & 0.01 & 0.42 \\
\hline IW & 0.25 & 0.25 & 0.30 & 0.13 & 0.01 \\
\hline ITO & 0.05 & 0.05 & 0.14 & 0.30 & 0.01 \\
\hline IRB & 0.15 & 0.15 & 0.10 & 0.05 & 0.01 \\
\hline
\end{tabular}

Table 10 presents the ranks of the alternatives for the considered set of criteria weights in Table 9.

Table 10. Ranks of alternatives with respect to the cases

\begin{tabular}{lcccccc}
\hline \multicolumn{1}{c}{ ALTERNATIVES } & $\begin{array}{c}\text { Present } \\
\text { case }\end{array}$ & Case 1 & Case 2 & Case 3 & Case 4 \\
\hline Innovation for automotive industry & $\mathbf{1}$ & $\mathbf{1}$ & 2 & 3 & 1 \\
\hline Innovation for military power & 3 & 3 & 3 & $\mathbf{1}$ & 6 \\
\hline Innovation for healthcare & 4 & 2 & $\mathbf{1}$ & 2 & 3 \\
\hline Innovation for environmental protection & 6 & 6 & 6 & 4 & 5 \\
\hline Innovation for agriculture & 5 & 5 & 5 & 5 & 4 \\
\hline Innovation for education & 2 & 4 & 4 & 6 & 2 \\
\hline
\end{tabular}


According to the obtained ranks in Table 10, the ranks of alternatives are not too sensitive unless the criteria weights are changed significantly. The alternative innovation for automotive industry has the first rank in three cases. The worst rank for this alternative is the third rank as in Case 3. The alternative innovation for environmental protection could not get a better rank than the fourth rank. The alternative innovation for healthcare got the first rank when the criteria increased welfare (IW), knowledge generation (KG) and innovation technological outcomes (ITO) have a significant increase in their weights and a significant decrease in the weights of demand for innovation investments (DII), investment in the research base (IRB), and increased productivity (IP). The alternative innovation for military power got the first rank when the criteria framework conditions (FC) and innovation technological outcomes (ITO) have a significant increase in their weights and a significant decrease in the weights of knowledge exchange efficiency (KEE), increased productivity (IP), and investment in the research base (IRB).

\section{Conclusions}

Innovative companies can improve their market shares by transforming their sources to investments. The relationship between a company's innovation activity and its investment activity is highly correlated. The nature of innovative activities undertaken by companies should be informative on the nature of investment activities. Investment intensity is a relevant explanatory variable for the occurrence frequency of innovation. We tried to express this relation using a multicriteria Fuzzy TOPSIS method including eight different criteria. The contribution of this paper comes from the first time use of a fuzzy multicriteria decision making methodology in the evaluation of technological innovative investments.

The alternative innovation for automotive industry is determined as the best alternative. The second and third ranks belong to the alternatives innovation for education and innovation for military power, respectively. The obtained results show that ranking is not sensitive to small changes in the criteria weights.

For further research, other multicriteria methods such as AHP, PROMETHEE, VIKOR, and DEMATEL can be used under fuzziness. Their results can be compared with this paper's. New innovation investment opportunities can also be considered additionally.

\section{References}

Aiello, G. 2009. Clean agent selection approached by fuzzy TOPSIS decision making method, Fire Technology 45: 405-418. http://dx.doi.org/10.1007/s10694-008-0059-3

Allred, B. B.; Park, W. G. 2007. The influence of patent protection on firm innovation investment in manufacturing industries, Journal of International Management 13(2): 91-109.

http://dx.doi.org/10.1016/j.intman.2007.02.001

Amiri, M.; Zandieh, M.; Soltani, R.; Vahdani, B. 2009. A hybrid multi-criteria decision-making model for firms competence evaluation, Expert Systems with Applications 36: 12314-12322.

http://dx.doi.org/10.1016/j.eswa.2009.04.045 
Andersson, R.; Quigley, J. M.; Wilhelmsson, M. 2009. Urbanization, productivity, and innovation: Evidence from investment in higher education, Journal of Urban Economics 66(1): 2-15. http://dx.doi.org/10.1016/j.jue.2009.02.004

BarNir, A.; Smith, K. A. 2002. Interfirm alliances in the small business: the role of social networks, Journal of Small Business Management 40(3): 219-232. http://dx.doi.org/10.1111/1540-627X.00052

Cavallaro, F. 2010. Fuzzy TOPSIS approach for assessing thermal-energy storage in concentrated solar power (CSP) systems, Applied Energy 87(2): 496-503. http://dx.doi.org/10.1016/j.apenergy.2009.07.009

Cumming, D. 2007. Government policy towards entrepreneurial finance: innovation investment funds, Journal of Business Venturing 22(2): 193-235. http://dx.doi.org/10.1016/j.jbusvent.2005.12.002

Davila, T.; Epstein, M. J.; Shelton, R. D. 2006. Making innovation work: how to manage it, measure it, and profit from it. Pearson education. Inc.

DeMarzo, P.; Kaniel, R.; Kremer, I. 2007. Technological innovation and real investment booms and busts, Journal of Financial Economics 85(3): 735-754. http://dx.doi.org/10.1016/j.jfineco.2006.07.003

Ekmekçioglu, M.; Kaya, T.; Kahraman, C. 2010. Fuzzy multicriteria disposal method and site selection for municipal solid waste, Waste Management 30: 1729-1736.

http://dx.doi.org/10.1016/j.wasman.2010.02.031

Fu, S.; Zhou, H.; Song, D.; Xiao, Y. 2013. Study on the performance evaluation of scientific innovation team in universities based on gray fuzzy theory, Information Technology Journal 12(4): 817-822. http://dx.doi.org/10.3923/itj.2013.817.822

Ghosal, V.; Nair-Reichert, U. 2009. Investments in modernization, innovation and gains in productivity: Evidence from firms in the global paper industry, Research Policy 38(3): 536-547. http://dx.doi.org/10.1016/j.respol.2008.10.010

Girma, S.; Gong, Y.; Görg, H. 2009. What determines innovation activity in Chinese state-owned enterprises? The role of foreign direct investment, World Development 37(4): 866-873. http://dx.doi. org/10.1016/j.worlddev.2008.07.017

Grenadier, S. R.; Weiss, A. M. 1997. Investment in technological innovations: an option pricing approach, Journal of Financial Economics 44(3): 397-416. http://dx.doi.org/10.1016/S0304-405X(97)00009-3

Huisman, K. J. M.; Kort, P. M. 2003. Strategic investment in technological innovations, European Journal of Operational Research 144(1): 209-223. http://dx.doi.org/10.1016/S0377-2217(01)00377-0

Hwang, C. L; Yoon, K. 1981. Multiple attribute decision-making: methods and application. New York: Springer. http://dx.doi.org/10.1007/978-3-642-48318-9

Ic, Y. T.; Yurdakul, M. 2010. Development of a quick credibility scoring decision support system using fuzzy TOPSIS, Expert Systems with Applications 37: 567-574. http://dx.doi.org/10.1016/j.eswa.2009.05.038

Iwaisako, T.; Tanaka, H.; Futagami, K. 2011. A welfare analysis of global patent protection in a model with endogenous innovation and foreign direct investment [online], [cited December 2012]. Available from Internet: http://www2.econ.osaka-u.ac.jp/library/global/dp/0924R.pdf

Kahraman, C.; Ates, N. Y.; Çevik, S.; Gülbay, M. 2007. Fuzzy multi-criteria evaluation of industrial robotic systems, Computers \& Industrial Engineering 52(4): 414-433.

http://dx.doi.org/10.1016/j.cie.2007.01.005

Kaya, T.; Kahraman, C. 2011 Multicriteria decision making in energy planning using a modified fuzzy TOPSIS methodology, Expert Systems With Applications 38(6): 6577-6585.

http://dx.doi.org/10.1016/j.eswa.2010.11.081

Kelemenis, A.; Askounis, D. 2010. A new TOPSIS-based multi-criteria approach to personnel selection, Expert Systems with Applications 37(7): 4999-5008. http://dx.doi.org/10.1016/j.eswa.2009.12.013 
Koski, T. M. 2003. Using fuzzy set theory in assessing the success potential of venture capital investment: theory and pilot field study, International Journal of Entrepreneurship and Innovation Management 3(5/6): 509-524. http://dx.doi.org/10.1504/IJEIM.2003.003940

Kutlu, A. K.; Ekmekcioglu, M. 2010. Fuzzy failure modes and effects analysis by using fuzzy TOPSIS-based fuzzy AHP, Expert Systems with Applications 39: 61-67. http://dx.doi.org/10.1016/j.eswa.2011.06.044

Lester, M. 2001. Innovation and knowledge management: the long view, Creativity and Innovation Management 10(3): 165-176. http://dx.doi.org/10.1111/1467-8691.00218

Liao, T.-S.; Rice, J. 2010. Innovation investments, market engagement and financial performance: a study among Australian manufacturing SMEs, Research Policy 39(1): 117-125. http://dx.doi.org/10.1016/j.respol.2009.11.002

Liu, W.; Han, N.; Zhang, C. 2014. The evaluation of innovation talent base on AHP-fuzzy in universities, WIT Transactions on Information and Communication Technologies 48(2): 725-732.

Lu, M.-T.; Tzeng, G.-H.; Tang, L.-L. 2013. Environmental strategic orientations for improving green innovation performance in fuzzy environment - using new fuzzy Hybrid MCDM model, International Journal of Fuzzy Systems 15(3): 297-316.

Maurer, B. 1999. Innovation and investment under financial constraints and product market competition, International Journal of Industrial Organization 17(4): 455-476. http://dx.doi.org/10.1016/S0167-7187(97)00047-7

Paksoy, T.; Pehlivan, N. Y.; Kahraman, C. 2012. Organizational strategy development in distribution channel management using fuzzy AHP and hierarchical fuzzy TOPSIS, Expert Systems with Applications 39: 2822-2841. http://dx.doi.org/10.1016/j.eswa.2011.08.142

Paunov, C. 2012. The global crisis and firms' investments in innovation, Research Policy 41(1): 24-35. http://dx.doi.org/10.1016/j.respol.2011.07.007

Peneder, M. 2008. The problem of private under-investment in innovation: a policy mind map, Technovation 28(8): 518-530. http://dx.doi.org/10.1016/j.technovation.2008.02.006

Reiss, A. 1998. Investment in innovations and competition: an option pricing approach, The Quarterly Review of Economics and Finance 38(3): 635-650. http://dx.doi.org/10.1016/S1062-9769(99)80094-5

Roghanian, E.; Rahimi, J.; Ansari, A. 2010. Comparison of first aggregation and last aggregation in fuzzy group TOPSIS, Applied Mathematical Modelling 34(12): 3754-3766. http://dx.doi.org/10.1016/j.apm.2010.02.039

Sadi-Nezhad, S.; Damghani, K. K. 2010. Application of a fuzzy TOPSIS method based on modified preference ratio and fuzzy distance measurement in assessment of traffic police centers performance, Applied Soft Computing 10(4): 1028-1039. http://dx.doi.org/10.1016/j.asoc.2009.08.036

Science and Innovation Investment Framework 2004-14. [online], [cited December 2012]. Available from Internet: www.bis.gov.uk/files/file39754.doc

Sun, C.-C.; Lin, G. T. R. 2009. Using fuzzy TOPSIS method for evaluating the competitive advantages of shopping websites, Expert Systems with Applications 36(9): 11764-11771. http://dx.doi.org/10.1016/j.eswa.2009.04.017

Sun, C.-C. 2012. A performance evaluation model by integrating fuzzy AHP and fuzzy TOPSIS methods, Expert Systems with Applications 37: 7745-7754. http://dx.doi.org/10.1016/j.eswa.2010.04.066

Wang, X. 2012. Foreign direct investment and innovation in China's e-commerce sector, Journal of Asian Economics 23(3): 288-301. http://dx.doi.org/10.1016/j.asieco.2010.11.007

Wang, Y. Q.; Jin, Q. Y.; Chang, Z. G.; Yao, L. X. 2014. The assessment and evaluation about the ability of technical innovation for petrol equipment manufacturing enterprises based on fuzzy comprehensive evaluation method, Advanced Materials Research 869-870: 1075-1079. 
Wickelgren, A. L. 2004. Innovation, market structure and the holdup problem: investment incentives and coordination, International Journal of Industrial Organization 22(5): 693-713.

http://dx.doi.org/10.1016/j.ijindorg.2003.06.003

Yager, R. R. 1982. Fuzzy sets and possibility theory. Oxford: Pergamon Press.

Ye, F. 2010. An extended TOPSIS method with interval-valued intuitionistic fuzzy numbers for virtual enterprise partner selection, Expert Systems with Applications 37(10): 7050-7055. http://dx.doi.org/10.1016/j.eswa.2010.03.013

Yong, D. 2006. Plant location selection based on fuzzy TOPSIS, International Journal of Advanced Manufacturing Technology 28: 839-844. http://dx.doi.org/10.1007/s00170-004-2436-5

Yoon, K.; Hwang, C. L. 1995. Multiple attribute decision making: an introduction. Thousand Oaks, CA: Sage Publications.

Asli SUDER. A full Professor of Management and Organization at Istanbul Technical University, Faculty of Management and Department of Management Engineering, in Turkey. Graduated from Bosphorus University Department of Management in 1976. Continued her education and also earned a Bachelor's Degree in Economics and Administrative Sciences from Marmara University, in 1981, a Master's Degree in International Management from Istanbul University, in 1982, and finally a Philosophy Degree in International Management in 1987 from Social Sciences Institute of Istanbul University. Published extensively in the field of Management and Organization, Human Resource Management, Project Management, Healthcare Management, Social Responsibility and Ethics, Logistics and Green Management, Crisis and Risk Management, Decision Making. Author of numerous scientific publications.

Cengiz KAHRAMAN. A full Professor of Industrial Engineering at Istanbul Technical University, Faculty of Management in Turkey. BSc, MSc, and PhD degrees are from Istanbul Technical University and on Industrial Engineering in 1988, 1990, and 1996, respectively. Main research areas are engineering economics, quality management and control, statistical decision making, and fuzzy sets applications. Published international journal papers over 170 and six edited books from Springer. Guest-edited many special issues of international journals. 